\title{
CUVÂNTUL TIMPULUI SAU DESPRE IMAGINEA VIEŢII ÎN VECHILE CRONICI
}

\author{
SvETLANA KOROLEVSKI \\ Institutul de Filologie Română „B. P.-Hasdeu” al MEC
}

\begin{abstract}
Rezumat. Marii cronicari ai Moldovei, Grigore Ureche, Miron Costin, Nicolae Costin, Ion Neculce, reprezintă, prin scrierile istoriografice pe care le-au elaborat, secţiunea de aur a literaturii române vechi din secolul al XVII-lea şi din primele decenii ale celui următor. Textele lor, ,au meritul capital de a fi construit, prin epica lor nonficţională, care istoriseşte fără să inventeze, secvenţe importante ale traseului povestirii culte româneşti". Intoarcerea către propriul trecut, în efortul de a povesti faptele „de la începuturi”, inţelegerea istoriei ca depozitară a unor modelelfaptel exemple necesare prezentului, dar şi viitorului, apelul constant la învățături şi pilde din gânditorii Antichităţii, aplecarea spre reflecţie, spre lumea interioară a omului sunt tot atâtea indicii care le îndrituiesc factura umanistă. Viaţa omului, viaţa lumii, sunt cele două dimensiuni concentrice pe care se axează discursul narativ, cronicile ilustrând, pregnant şi tulburător, cât să nu să treacă cumva cu nitarea, lucrurile şi cursul țării. Revenim din timp în timp la vechile texte, pentru că ele, incitante şi revelatoare, ne apropie de universul lumii de ieri şi ne ajută să-l prefigurăm pe cel al lumii de mâine.
\end{abstract}

Cuvinte-cheie: cronici, viața omului, viața lumii, recitire, modele umane.

Abstract. The great chroniclers of Moldova, Grigore Ureche, Miron Costin, Nicolae Costin, Ion Neculce, represent, by their historical works, the golden segment of old Romanian literature from the 17 th century, and from the first decades of the following century. Their works ,have the important aim of building, through their non-fiction epic which narrates without inventing, important parts of the path to Romanian narrative". The return to their own past in an effort of telling the facts ,from the beginnings", understanding history as a keeper of some models / facts / examples necessary to the present and the future, the constant calling to teachings and examples of the antique thinkers, the inclination towards reflection, towards the man interior world - are as much hints created by the humanitarian faction. The man's life, the world life, are those two concentric dimensions which create the root of narrative discourse, the chronicles illustrating in a disturbing way, so they won't be forgotten, the things and the country's course. We are returning from time to time to the old texts because they, as inciting and revealing as they are, got us closer to the universe of yesterday and help us to build the one of tomorrow.

Keywords: chronicles, man's life, world's life, reread, human models.

Pe urmele lui Eminescu, revenim continuu la vechile texte, din zorii plămădirilor noastre, pentru că în ele ne regăsim, ne recunoaştem, ne confirmăm. 
Viitorul şi trecutul/ Sunt a filei două feţe/ Vede-n capăt începutul/ Cine ştie să le-nveţe, glosa, magistral, poetul, arcuind gândul şi în publicistica sa, care, se ştie, reia, ca în oglindă, întreaga-i cuprindere vizionară. Trecutul, după propria-i mărturisire, 1-a fascinat întotdeauna. Citim în Timpul de la 1881: „Oare n-am uitat cumva că iubirea de patrie nu e iubirea brazdei, a ţărânei, ci a trecutului?”. Se întreba, răsfoind vechi izvoade (citând sfaturile lui „Neagoevodă, om mai mult sfầnt decât războinic, către fiul său Theodosie”, ,,cronicile noastre; descrierea din vremea lui Matei Basarab făcută de diaconul Paul din Aleppo”, „cartea românească numită Ceasornicul Domnilor care cuprinde în mai multe volume atât înfăţişări din viaţa trecutului cât şi norme de virtute şi înţelepciune" şi multe alte), atenţionându-şi contemporanii (dar şi pe noi), că orice civilizaţie adevărată nu poate consista decât într-o parţială întoarcere la trecut, la elementele lui bune, sănătoase, proprii de dezvoltare (Eminescu, 2001, pp. 343, 417, 643).

„A vorbi despre Cartea veche înseamnă a vorbi despre Istoria Țării”, ne va spune, un secol mai târziu, Nicolae Dabija, în Antologia poeziei vechi moldoveneşti, apărută la Chişinău, în 1987, şi, tot acolo: „Cărţile vechi răsfrâng cerul sub care au fost caligrafiate şi chipurile celor care le-au scris” (Antologia..., Chişinău, p. 15 ), îndemnându-ne să medităm asupra mesajului vibrant al literaturii române vechi, ca spaţiu al cunoaşterii şi al definirii noastre, să valorizăm întreaga moştenire culturală, inclusiv scrierile de expresie slavonă - pentru că astfel restituim patrimoniului nostru ceea ce-i aparţine pe bună dreptate; iar Eugeniu Russev scotea monografia Cronografia moldovenească din veacurile $X V$-XVIII (1977), rod cumulativ al unor îndelungi investigaţii privind legătura organică şi succesiunea, de-a lungul secolelor, a marii şcoli cronicăreşti din Moldova, întemeiată pe vremea lui Ştefan cel Mare şi până la Ion Neculce. „Trecutul şi prezentul se află într-un dialog permanent, necesar, inevitabil" (Zub, 2004, p. 49).

Anii '80 ai secolului trecut au însemnat, de altfel, o reanimare a interesului pentru cercetarea textelor vechi, relectura şi valorizarea acestora materializându-se în abordări relevante privind coordonatele estetice şi civilizaţionale ale scrisului vechi românesc. Aceste contribuţii veneau să completeze sintezele consacrate în domeniu, de la Iorga încoace.

Mircea Scarlat, Valeriu Cristea, Virgil Cândea, Doina Curticăpeanu, Mircea Anghelescu, Cătălina Velculescu, Dan Horia Mazilu, Dan Zamfirescu, Eugen Negrici, Elvira Sorohan sunt primele nume care-mi vin în minte, cărora li se alătură, de la Chişinău, Pavel Balmuş, Andrei Eşanu, Mihai Cimpoi sau Gheorghe Bobână.

De fiecare dată cercetarea va avea, va trebui să aibă ,atributele unei mereu reînnoite pledoarii”, reţinem din aserţiunile Doinei Curticăpeanu, căreia îi datorăm un studiu de referinţă:

Orizonturile vieții în literatura veche românească, care ne facilitează şi ne motivează accederea în lumea textului vechi, decriptându-ne înţelesuri, 
făcându-ne atenţi şi la oamenii care le-au scris, „oameni care au avut o nedezminţită vocaţie a duratei” (Curticăpeanu, 1975, p. 185).

Înainte de toate, însă, trebuie să ai un gust rafinat printr-un lung exerciţiu, după buna subliniere a lui George Călinescu, ca să poţi asculta pulsaţia încă vie a acestor pagini; sau, într-o altă cheie, demnă şi aceasta de reţinut, a unui alt împătimit al textului vechi, Eugen Negrici, care zice undeva, şi-mi place să repet: Literatura română veche, pentru a fi inţeleasă, trebuie mai întâi iubită.

Textele vechi trebuie citite cu multă răbdare, uneori cu creionul în mână şi cu acea înţelegere că ele ,se adresau unui public care trăia, vedea lumea şi privea omul altfel decât noi” (Duţu, 1982, p. 69).

Cei vechi puneau preţ pe cuvânt, pe forţa stimulatoare a acestuia. După Ernst Cassirer, ,în vechime cuvântul avea mai ales o funcţie mitică, dar şi magică; invocat, acesta putea crea, modifica şi dizloca lumea" (Cassirer, 1994, p. 154).

„Eu spui domnie-tale, iar domniia-ta eşti înţelept şi aceaste cuvinte să ţii domniia-ta la tine", citim în Scrisoarea lui Neacşu, primul text românesc datat, 1521 (Literatura română medievală, 2003, p. 4); „,cuvântul iaste ca vântul: deaca iase din gură, nici într-un chip nu-l mai poţi opri, măcar de teai căi şi ziua şi noaptea, nimic nu vei folosi”, desprindem din Invăţăturile lui Neagoe Basarab către fiul său Theodosie (Literatura..., 2003, p. 34).

Marii cronicari ai Moldovei, Grigore Ureche, Miron Costin, Nicolae Costin, Ion Neculce, reprezintă, prin scrierile istoriografice pe care le-au elaborat, secţiunea de aur a literaturii române vechi din secolul al XVII-lea şi din primele decenii ale celui următor.

Textele lor ,au meritul capital de a fi construit, prin epica lor nonficţională, care istoriseşte fără să inventeze, secvenţe importante ale traseului povestirii culte româneşti” (Mazilu, 2003, p. XL). Întoarcerea către propriul trecut, în efortul de a povesti faptele „de la începuturi”, înţelegerea istoriei ca depozitară a unor modele/fapte/exemple utile prezentului, dar şi viitorului, apelul constant la învăţături şi pilde din gânditorii Antichităţii, aplecarea spre reflecţie, spre lumea interioară a omului - sunt tot atâtea indicii care le îndreptăţesc factura umanistă. Cursul textului urmează modelul cursului vieţii, recuperând sensurile lumii şi ale trecerii în mod diacronic, iar omul este surprins în momente esenţiale ale existenţei sale. Frescă nu doar a evenimentelor, ci şi a ritmului trăirii, a sensibilităţii timpului însuşi, textele vechi, dincolo de abundenţa informaţiei, fac dovada unui model de viaţă.

Viaţa omului, viaţa lumii, sunt cele două dimensiuni concentrice pe care se axează discursul narativ, cronicile ilustrând, pregnant şi tulburător, cât să nu să treacă cumva cu uitarea, lucrurile şi cursul ţării. Omul şi oamenii oameni vii, învolburaţi într-o lume marcată de neprevăzut, suferinţă, angoasă, nelinişte, resemnare; dar şi speranţă în vremuri mai bune.

Pentru cărturarii secolului al XVII-lea românesc „credinţa în rolul culturii, cultivarea înţelepciunii, căutarea imaginii pierdute a trecutului, apelul 
la autorităţi străine tradiţiei, dezvoltarea conştiinţei de neam, mândria originilor, funcţiunea majoră a scrisului şi tiparului” au fost definitorii (Cândea, 1979, p. 325). Cronicarii vor preţui cartea/cărţile şi vor nutri o consideraţie sacră față de cuvântul scris, ,că scrisoarea, iscusită oglindă minţii omenești, ieste un lucru vecinicŭ” (Costin, 1958, p. 243).

Gândind şi simţind în spiritul veacului al XVII-lea european, era firesc ca Miron Costin (ca să mă opresc doar la un exemplu) să elogieze cartea şi lectura, din care înţelegea să facă ,iscusită zăbavă”. Acest credo al vieţii sale a căutat să-l afirme prin exemplul propriei creaţii.

„Originalitatea lui Costin, consideră N. Manolescu, vine din aplecarea spre culisele istoriei. Dacă la Ureche aveam sub ochi numai faţa covorului, la Costin avem, de multe ori reversul lui, plin de fire şi noduri” (Manolescu, 1990, p. 53).

Ochiul naratorului contemplă/reconstituie/rememorează o lume a Moldovei, spectacolul vieţii în toată complexitatea sa, dar şi lumea/lumile din vecinătatea imediată; relatarea faptelor petrecute dincolo de fruntariile ţării îi stăpâneşte constant, însuşindu-şi din start că străinul se cuvine cunoscut şi integrat într-un sistem de valori, construcţia imaginii celuilalt servind la nuanţarea propriei imagini: ,Şi acéia să să ştie că această ţară fiindŭ mai mică, nice un lucru, sângură den sine, fără adunare şi amestec cu alte ţări, n-au făcut" (Costin, 1958, p. 130).

Astăzi, trecând proba timpului, opera costiniană îşi reliefează şi mai pregnant durabilitatea valorică. „Chiar după o frecventare îndelungă a operelor epice ce i-au urmat în timp, farmecul cronicii minunatului nostru om de cultură nu poate fi alterat de vreo pretenţie estetizantă contemporană, dat fiind şi faptul că multe din elementele conştiinţei literare moderne îşi găsesc expresia într-un fel sau altul şi la el" (Cimpoi, 1982, p. 339). Analizate, în cheia lectorului de azi, textele vechi dezvoltă noi dimensiuni (Negrici, 2000, p. 649).

Axat pe dimensiunea existenţială, discursul costinian ne propune să medităm la Timp, ca supremaţie dominatoare (vremea/vremile socotelii; $n u$ sintú vremile supt cârma omului, ce bietul om supt vrémi); la rosturile ascunse ale Firii (zburdeadză hirea omenească); la Jocul imprevizibil al sorţii (orbú nărocul la suişs). Expresia unui timp umanizat străbate veacurile, aruncând punte în viitor: „Mă vei ierta, iubite cititoriule, căci nu ţ-am scris acéste semne la locul său. Crede neputinţii omeneşti, créde valurilor şi cumplitelor vrémi, intreabă pe ce vrémi am scris şi cât amŭ scris. Aş hi lipit acéste sémne la rândul său, ce amu era trecut rândul la izvodul cel curat şi scriitori carii izvodescŭ puţini să află, iară tipar nu-i" (Costin, 1958, p. 165). Tensionată, impregnată de neliniştea veacului şi a omului, apare construcţia narativă costiniană.

Europenii secolului al XVII-lea, citim în volumul Omul baroc, coordonat de Rosario Villari, ,,au avut şi ei o viziune deosebit de dramatică a perioadei în care au trăit, pe care au reuşit să o transmită posterităţii: veac de fier, mundus furiosus, epocă de răscoale şi agitaţii, opresiuni şi intrigi, în care oameni, 
deveniţi lupi, se mănâncă unii pe ceilalţi, epocă de dezordine, de distrugere, de răsturnare a ierarhiei, de veleitarism; pe scurt, o epocă a marilor tensiuni, considerate adesea pur şi simplu negative, mai curând decât etape necesare pentru atingerea unui echilibru social şi politic superior şi a unei capacităţi creatoare mai profunde şi mai cuprinzătoare” (Villari, 2000, p. 8-9).

Contemplând şi analizând rostogolirea „cumplitelor vremi”, cronicarul este, în acelaşi timp, conştient de imposibilitatea echivalării timpului istoric cu timpul narării. „Ceea ce povesteşti repede nu se întâmplă tot aşa de repede”, observă Miron Costin, care, insistând asupra însemnătăţii faptelor trecute, anticipează deseori deznodăminte viitoare. Efortul de înţelegere a condiţiei umane transpare din paginile operei sale.

Ce este dar lumea, ce este omul în împărăţia lumii acesteia trecătoare? Această formulare, esenţială, pentru că înglobează în sine un tot: faţa zilei de ieri, şi a celei de azi, şi a celei de mâine, - pe care o desprindem din Învătăturile... lui Neagoe Basarab (cel pe care Academia Română l-a comemorat chiar în această toamnă - cinci secole de la trecerea în veşnicie), o regăsim în paginile lui Miron Costin (dar nu numai), pagini în care preocuparea asupra condiţiei umane capătă contur inconfundabil.

În acelaşi timp, opera sa reflectă artistic o realitate dată, cronicarul memorând şi rememorând evenimente la care a participat sau care l-au marcat, actualizându-le. Miron Barnovschi (care, prin nume şi tragicu-i final, aminteşte însuşi destinul cronicarului) este decapitat la Constantinopol în chiar anul naşterii lui M. Costin; Vasile Lupu, după fericita-i domnie - închis la Edi Cule, soarta fiindu-i, astfel, pecetluită; Simion-vodă otrăvit de ambiţioasa şi avida de putere doamnă a lui Ieremia Movilă, ca mai apoi să i se spulbere şi acesteia, într-un mod neiertător, visurile de mărire - „Iar moartea lui [a lui Simion-vodă - n.n.], precum au rămas den om în om în ţară poveste, au murit otrăvit de cumnată-sa, de doamna lui Ieremiei-vodă, trăgândŭ domniia mai curundŭ la feciorii săi, temându-să că să vor întémeia feciorii lui Simion-vodă la domniia ţării, care fapte acéi doamne apoi mai pe urmă au arătat Dumnedzău cu patimile ei" (Costin, 1958, p. 57); sângeroasa domnie a lui Ştefan Tomşa, luarea Cameniţei de către turci, pierdere retrăită dureros de autor - iată doar câteva dintre dramaticele subiecte ce caracterizează acea epocă plină de zbucium şi nelinişte. În doar 65 de ani (de la Aron-vodă până la Ştefăniţăvodă) 22 de domni trec din mână în mână sceptul ţării. Cel mai adesea domnii sfârş̧esc prin a fi maziliţi. Pâra (sau ,şoapta”, vorba cronicarului) odată ajunsă la Poartă, încercarea domnului căzut în dizgraţie de a se reabilita devine posibilă doar în schimbul a mari sume de bani. Prima mazilire a Ducăi-vodă a generat trei domnii într-un singur an, pentru fiecare plătindu-se câte 500-600 de pungi. „Den care faptă se stânge ţara Moldovei” (Costin, 1958, p. 123). O naraţiune care abundă în situaţii/ stări pătrunse de fiorul trăirii umane.

Istoria vieţii lui Miron Barnovschi impresionează. Acest domnitor, pentru care cronicarul pare a fi avut toată simpatia, deşi ,trufaş şi la portul hainelor mândru, iară la inimă foarte direptu şi nelacom şi blându”, cu „,multe 
bunătăţi era spre ţară", zidind în numai trei ani mănăstiri şi biserici cât alţii în 20 de ani sau mai bine. Acceptă cu bucurie vestea că ţara-l vrea din nou domn. „Neştiutor gândul omenesc singur de sine la ce merge şi la ce tâmplări apoi soseşte" (Costin, 1958, p. 100), constată cu amărăciune cronicarul, anticipând trista derulare a evenimentelor. „Dulce este domnia de Muldova!” - ar fi răspuns Barnovschi la sfatul vecinului său leah de a nu-şi da „viaţa fără grije pe viaţă cu grije şi cu cumpănă”. „Iară şi obedzăle turceşti încă sintu grele! ar fi stăruit din nou vecinul, şi soarta a vrut ca el să aibă dreptate. Neprietenii cu limba lor amară au mâncat capul lui Barnovschi-vodă - notează plastic autorul, împărtăşindu-ne din subterfugiile celor ahtiaţi de putere. Sfârşitul vodă 1-a intuit fiind în închisoare, de unde a şi scris mamei sale - „o carte în ţară la îmma sa”. „Iar calul său, în aceeiaşi zi s-au trântitŭ gios şi au muritŭ în locŭ, întâmplare care nu numai în ţară aicea, ce plin este Ţarigradul pănă astădzi”. Semne s-au arătat în continuare, a doua zi noaptea arzând la Țarigrad câteva mii de case, plusează cronicarul, sugerând nevinovăţia domnitorului - ,au arătat Dumnedzău sânge nevinovat, că era Barnovschii om dumnădzăierescu şi mare rugătoriu spre Dumnedzău" (Costin, 1958, p. 103).

De observat, că în mentalul colectiv al secolelor trecute, soarta omului e decisă de instanţa supremă, pronia cerească orânduind lucrurile să se desfăşoare într-un fel anume. Evenimentele esenţiale ale parcursului uman de la naştere la moarte - toate se petrec sub zodia acestei ,încuviinţări” divine, ilustrată în cronici din plin („Iară poate hi că giudeţul lui Dumnedzău spre ce trage, cu anevoie să mută cu sfatul omenescu" (Costin, 1958, p. 144).

Subtil observator al fenomenelor psihice şi al sufletului uman, Costin surprinde exact firea personajelor sale - oameni reali, puşi în situaţia de a înfrunta intemperiile vieţii. „Destinul pentru Costin stă înscris în chiar imanenţa umană şi istorică” (Manolescu, 1990, p. 52-53).

Preocupat în permanenţă de comportamentul personajelor sale, M. Costin demonstrează pătrundere psihologică, căutând să surprindă stările interioare ale acestora, nota dominantă pe care o dă hirea (Nestătătoare şi lunecoase hirile omeneşti; Nesăţioasă hirea omenescă la măriri). „Mică ţintă este omul”, ,în mică cumpănă stau lucrurile omeneşti şi răssipele a mare case şi domnii şi bine au dzis un dascal că lucrurile războaielor în clipala ochiului stau” (Costin, 1958, p. 164); „Iară ce este să nu treacă, cu anevoie să mută cu sfatul” (Costin, 1958, p. 131); „Să socoţi mai întâi lucrul, nu mai pe urmă” şi „să frămânţi cu voroava lucrul” - spre aceste două postulate îndeamnă, în repetate rânduri, cronicarul, căci, „la mulţi domni, mare smentele am vădzut den şoapte sau nesfătuit" (Costin, 1958, p. 122).

„Iar ce-ţi pare numai a singur că este bine şi alţii toţi dzic că este întraltŭ chip, să nu crédzi acéia socoteală, că te amăgeşte. Multe lucruri ne parŭ că sintŭ gâcite, iară apoi, dacă mai laşi vrémea socotelii, afli departe, mai pre urmă, într-altŭ chip" (Costin, 1958, p. 122).

Amplificările lui merg în direcţia conturării împrejurărilor în care faptele se produc, detalierea urmărind să reţină datele comportamentului oamenilor 
surprinşi în manifestările cele mai neaşteptate. Tabloul, foarte viu, în iureş, în mişcare, al oştii lui Ştefan-vodă domnul de Moldova este copleşitor, dar şi foarte instructiv: ,... au început a striga toţi în toate părţile: «Haida, haida, la ei, la ei». Neaşteptând nice porunca, nice vremea, nici tocmală, nici pre lângă sine vreo tabără, cum se cade unii pedestrime să margă, ce, care cum putea mai înainte, cum ar hi la lucru gata, mâna bivolii carii trăgea puşcile, tot în biciŭ, nice la un loc încă strânsă oastea, ce care cum putea, buluc după buluc mai tare. Şi cum au sosit la vadul Teleajinului, cum au început a da cu sinéţele şi deodată să stoliia, pănă ari agiunge şi celelalte bulucuri. Iar ce tocmală să hie la o oaste care era ca un roi fără matcă . Puşcile cum au sosit la apă, bivolii pre hirea sa, năduşiţi şi de căldură, că era vara, şi de osteneala călii pripiţi, cum au vădzut apa, cum au năvălitŭ într-apă préste oameni și au băgat puşcile într-apă după sine" (Costin, 1958, p. 172), pentru că subliniază, o dată în plus, tenta moralizatoare a scriiturii.

Textele relevă dramatismul existenţei, dar şi momentele de linişte, de calm, de zăbavă.

În De neamul moldovenilor, din ce țară au ieşit strămoşii lor, Costin ne dă detalii preţioase despre modul de viaţă, despre anumite tradiţii perpetuate secole la rând, cum ar fi „,...obiceiul meselor şi ospeţelor, carii să văd că-s vechi ţinute aicè într-aceste ţări și le ieste de la vechii romani, precum a închina păhar pentru sănătăţile priietinilor ş-a împăraţilor... Acestŭ obiceiŭ şi la nemţi şi la unguri, la ardeleni, vechii romani şi la noi pe urmă, de pomenesc la mese sănătăţile domnilor cu păhare pline de băuturi, aşè şi a priietinilor" (Costin, 1958, p. 272).

Relevantă în cronici este, mai ales, acea „vreme a socotelii”, când se trece de la naraţiunea propriu-zisă la parabolă, la generalizare, iar prin aceasta - la o verificare, la confruntare cu timpurile viitoare. Au căutatŭ a face Vasilie-vodă şi veseliia fiei sale, Roxandei, după Timuş, feciorul lui Hmil, hatmanul căzăcescŭ şi câte trebuia la o nuntă domnească, nemică n-au lipsit, precizează Costin, deloc încântat însă de această netocmală a caselor şi a hirelor, (,ginirile singur faţa numai de om, iar toată hirea de hiară"), întâmplările de mai târziu confirmând această previziune: „,s-au desfrânat la jacurile mănăstirilor, cu puşci au mărsŭ şi au bătut mănăstirea [Dragomirna $-n . n$.], ruşinândŭ căzacii fămei şi fete şi nu ca creştinii, ce mai multŭ decât păgânii s-au purtat. Şi să hie mai avut vréme cevaşi Timuş, nici o mănăstire n-ar hi hălăduit... Şi acéle puşci apoi curundŭ au scurtatŭ dzilele şi a lui Timuş, cu direptŭ giudeţul a lui Dumnedzău, pentru prada care făcuse beséricilor" (Costin, 1958, p. 159-163).

Profund marcat de accentul moralizator (s-a scris mult despre ecourile livreşti în opera lui Costin, despre aforismele şi numeroasele maxime/sentinţe morale pe care naratorul le are întotdeauna la îndemână), discursul costinian se impune prin funcţia sa modelatoare, istorisirea faptelor întâmplate aievea de fiecare dată convertindu-se în parabolă, spre luare aminte.

Neculce, ,cel care $s-a$ zidit $[s . n$.] în cronica sa, începută, în planul subconştient al fiinţei, din nevoia de a se apăra" (Cristea, 1974, p. 148-149), 
ne spune, cu o formulă demnă de reţinut, Valeriu Cristea (sintagma trimite, involuntar, la mitul Meşterului Manole), a avut un adevărat har al povestirii.

„Cu o nedezminţită vocaţie, Neculce se amestecă printre oamenii de care vorbeşte, înfăţişează această lume dinlăuntrul ei” (Curticăpeanu, 1975, p. 113). Doina Curticăpeanu care a încercat şi o configurare menită să arate „spiritul" în care a lecturat cronicarul izvoadele pe care le-a luat ca sursă, a putut constata că faţă de relatarea sumară a surselor, cronica lui Neculce vine cu explicaţii suplimentare, completând şi animând spaţiul lăsat de faptele insuficient epicizate de izvoare, reconstituind, credibil!, scene şi replici în potrivire cu contextul. Fiind întotdeauna preocupat de motivarea acţiunilor, Neculce adaugă menţiunilor fugare ale izvorului explicaţia, amănuntul, efectul de surpriză, insuflând viaţă ,,paginilor aride pe care le consultă” (Curticăpeanu, 1975, p.74-78) şi transformându-le în adevărate sclipiri literare, omul şi obiceiul nărodului omenescu apărând în prim-planul narațiunii sale. Doar un exemplu, din acest mozaic plin de culoare al vieţii de altădată:

„,...S-au gătit împărăţia Turculi şi au purces cu oşti să vie asupra Țării Leşeşti, să dobândească vestita cetate Cameniţa. Şi au trimis poroncă la Duca-vodă să-i trimiţă chip şi starea cetăţii Cameniţii, să vadză ce loc şi ce tărie arŭ avè. Duca-vodă au triimis pe un nemiş din ţinutul Hotinului, anume Gligorie Cornescul, ce era foarte meşter de scrisori şi de săpături la pietre şi la alte lucruri, de au făcut chip cetăţii Cameniţii de ceară, cu toate tocmelele ei dinluntru şi denafară. Şi o au trimis la împărăţie, de o au vădzut, şi mult s-au mirat de mărirea ei, ce era din sângură starea locului, cu apă şi cu stânci de piatră împregiuriu, minunat locŭ. Şi mai mult aceasta au îndemnatŭ pe împărăţie de au vinit la Cameniţă...

Într-acestu anŭ făcutu-s-au şi o minune mare, arătare la Hotin, într-o mănăstioară mică ce este supt cetate. Au lăcrămat icoana Maicii Precistei, cât să răntuna lacrămile pe chipul icoanei, de le vidè toţi oamenii. Şi pica într-o tepsie ce era pusă supt icoană, de era de mirare a prăvi arătarea şi sămnu ca acela, carele au fostu adevărat sămnu de peire a mulţi creştini în Ţara Leşască şi începătura durerei şi stricărei ţării noastre. Că de atunce din an în anŭ tot rău şi amar de creştini şi pustiire au rămas locurile pre acolo (Neculce, 1958, p. 42).

Viaţa, dar şi reversul acesteia - moartea, marea trecere, implacabilă, de neocolit.

Cum percepeau cei vechi, strămoşii noştri, această rupere? Textele vechi ne dau un răspuns. Unde este viaţă este şi moarte, căci începem să murim chiar din momentul naşterii (Veacul nostru cu-mprumut dat în datorie). Toate au un sfârşit, chiar şi astrii (Voi, stele iscusite, ceriului podoba,/Vă aşteaptă groaznică trâmbiţa şi doba; Şi voi, lumini de aur, soarile şi luna,/ Intuneca-veţi lumini, veţi da jos cununa), ne spune Costin în poemul său filosofic Viiaţa lumii.

Imaginea morţii ocupă un loc semnificativ în economia textului vechi. Dovada importanţei acordate acestui eveniment este chiar menţionarea lui în 
cronici (detaliat, laudativ sau moralizator, pe linia după faptă-pedeaps $\breve{a}$; de cele mai multe ori punctându-se şi ,,portretul” personajului sau chiar contextul social, calamităţile naturale din vremea dată). O uimitoare diversitate a tipurilor de moarte vom afla consemnate în cronici (Dobre-Bogdan, 2002, p. 121). Cronicarii construiesc retoric secvenţa morţii, în funcţie de rangul personajului, perpetuarea memoriei celui trecut la cele veşnice fiind condiţionată de fapta cea bună, moment consemnat de toţi cronicarii şi de autorul poemului amintit mai devreme (Una fapta, ce-ţi rămâne, buna, te lățéşte, I In ceriŭ cu fericie în véci te măréş̧te), moartea provocată de o calamitate a naturii fiind văzută şi ea ca pedeapsă de origine divină.

„Chiar episodul cel mai duios şi poate mai dramatic din opera lui Neagoe Basarab, - ne spune Ştefan Ciobanu în Istoria sa, - tânguirea sfâşietoare cu ocazia morţii fiului său [Petru - n.n.], episod care poate să aibă şi un substrat real, poate să fie o manieră de a scrie, o formă literară, pentru a arăta zădărnicia acestei vieţi... Să ştii să-ţi aperi moşia, să nu-ţi părăseşti ţara niciodată, să mori pentru ea, este idealul autorului, care ne aminteşte idealurile cavalerilor din Evul Mediu. Şi peste toate, ca la aceiaşi cavaleri din Evul Mediu, credinţa fierbinte în Dumnezeu, îndeplinirea poruncilor lui şi spiritul larg de omenie, de toleranţă faţă de slăbiciunile omeneşti şi de iubire creştinească ...Însuşirile ei poetice aşază această operă printre scrierile cele mai de seamă ale literaturii noastre vechi" (Ciobanu, 1989, p. 50-52). Şi Nicolae Cartojan distinge acest pasaj memorabil (,durerea îi sângerează sufletul pentru moartea prematură a fiului său Petru") din Învăţăturile lui Neagoe Basarab către fiul său Theodosie, scriere parenetică mult gustată de-a lungul timpului, la care facem neîncetat trimitere (Cartojan, 1996, p. 80-81).

Monumentalul, foarte des citatul portret (de care Eminescu era încântat) al lui Ştefan cel Mare, sculptat în cuvânt de Grigore Ureche, îl aflăm anume în capitolul intitulat De moartea lui Ştefan -vodă celui Bun, vă leato 7012 $<1504>$. Urmează alte câteva detalii demne de reţinut („Ce după moartea lui, până astăzi îi zicu sveti Ştefan-vodă, nu pentru sufletu, ce este în mâna lui Dumnezeu, că el încă au fostu om cu păcate, ci pentru lucrurile lui cele vitejeşti, carile niminea din domni, nici mai nainte, nici după acéia 1-au ajuns. Fost-au mai nainte de moartea lui Ştefan-vodă într-acelaşi anu iarnă grea şi geroasă, câtu n-au fostu aşa nici odinioară, şi décii preste vară au fostu ploi gréle şi povoaie de ape şi multă înecare de apă s-au făcut. Au domnitu Ştefanvodă 47 de ani şi 2 luni şi trei săptămâni şi au făcut 44 de mănăstiri şi însuşi ţiitoriu preste toată țara"), precizări care aduc un plus de veridicitate relatării, nuanţează şi fac mai credibilă consemnarea (Marii cronicari..., 2003, p. 93).

Miron Costin, copleşit de confruntarea cu realitatea extremă, este, uneori, de un laconism dramatic: „Să prăveşti moarte, să vedzi osânda şi aşea de sârg vărsare de sânge de oameni! Era trei iazuri de trupuri, cum sta trei rânduri de pedestrime, unul preste altul de pe subt mal, până la pârâul Bahluiului” (Costin, 1958, p. 193); „I-au cuprinsŭ şi i-au omorât, iară altora leau tăiat urechile" (Costin, 1958, p. 156); alteori, relatând în amănunt parcursul 
implacabil al sfârşitului: „Numai ce au căutat a purcéde Ştefăniţă-vodă şi-n cale mergândŭ, amu de Tighinea aproape, pe Bâcŭ, la un sat anume Luţenii, au căzut în boală foarte grea, lungoare, care boală au priceput îndată doftorul că trebuie să ia sânge, ce n-au ascultat şi adăogându-să boala şi ales toamna amu, aşea de greu l-au cuprins herbinţeala, cât pănă la Tighinea au stătut frănitic, adică buiguit de hire. $\mathrm{Cu}$ chipul ciumii era boala, că i-au ieşit şi bolfa la o mână, însă nu era ciuma, ci direaptă lungoare carii boli îi dzic doftorii maligna. Şi cât au trecut la Tighinea Nistrul, au stătut a treia dzi mortŭ... Şi au venit în Iaşi şi l-au astrucat în mănăstirea tătâne-său, care să pomeneşte pre numele Trei Svetitelei" (Costin, 1958, p. 200-201). Fragmentul, uşor retoric, în perfectul stil istoriografic, aduce nu numai claritate, dar şi sensibilizeză, patosul concentrat umanizând tiparul canonic.

Memorabila poveste a lăcustelor, (,care cu ochii cumŭ veniia am prăvit, eram pre atuncea la şcoală la Barŭ”), urgia care pustieşte locul pe unde trece, punctează şi ea o imagine a neprevăzutului, a provizoratului în această lume, şi indică asupra unui gând frecvent reluat de Costin: semnul divin planează peste tot ce mişcă sub soare, mânia/pedeapsa lui Dumnedzău este de neevitat: „Că era să să pomenească la domniia lui Vasilie-vodă, pentru cometa adică steaoa cu coadă, care s-au prilejit cu câţiva ani mainte de aceasta, aşea de grea premeneală aceştii domniei şi întunecarea soarelui, în anul acela, în care an s-au rădicat Hmil-hatmanul cu căzacii asupra leşilor, foarte groazdnică întunecare în postul mare, înaintea Paştilor, în anul <7156>, într-o vineri, şi tot într-acela an lăcustele neaudzite vacurilor, care toate semnele în loc bătrânii şi astronomii în Țara Leşască a mare răutăţi că sintŭ acestor țări meniia”(Costin, 1958, p. 165).

Moartea unui adversar şi expunerea trupului mort în văzul mulţimii, spre luare aminte şi înfrânare ,,făcea parte din pedagogia punitivă a lumii medievale” (Lemny, 1990, p. 122). Neculce ne relatează asemenea ,practici”, curente în epocă („După ce au aflat Brâncovanul pe Bălăceanul mort în războiu, trimisui-au capul în Bucureşti, de l-au pus într-un prepeleac în mijlocul ogrădzii lui, de-au şedzut vr-un an cu capul în prepeleac. Şi au învăţat de i-au răsipit şi curţile şi ograda, de-au rămas numai jărişte" (Neculce, 1959, p. 105), inclusiv despre codrenii-tălhari, prinşi de vii, înţepaţi şi spânzuraţi, omorâţi cu fel de feluri de cazne: „Aşijdere şi Miron-logofătul, fiind staroste la Putna, au fãcut siimeni şi hânsari ş-au început şi dintr-acolo a răsăpi tălharii. Că numai o dată la o bătaie au prinsu 40 de tălhari şi i-au tăiat câte în patru bucăţi, de i-au pus pen prepeleci pe la drumuri” (Neculce, 1959, p. 99).

Miron Costin, în lucrarea sa monografică, menţionează şi obiceiurile de îngropăciune în ţările româneşti: „La acestea şi obiceiul ce stă încă întraceste ţări adecă aicè la noi şi la munteni şi la darea datoriei de opşte, adică la moarte, vechiŭ obiceiŭ", - remarcă M. Costin, - întărind cu citate din Topeltin: „În Ardeal dachilor obiceiŭ cu mare petrecere a duce mortul la groapniţa; mărgŭ înaintea boierilor cântăreţii şi preuţii, pe urmă viniia cielaltă mulţime, închipuind cum şi cielalţi vor merge unde şi cel mortŭ, ca cum ar dzice: mergi, 
că noi te vom urma...Şi iar tot acel Topeltin dzice: «Muierile daţilor osăle părinţilor, a ficiorilor, a bărbaţilor şi altor rudenii cu bocet nespus mărgŭ după ose, cu plânsuri de mirat şi cuvinte de jele cuprindŭ osăle şi cu glas mare toată viiaţa omenească o plângŭ. Scrie Varro în cartea a 4, de viiaţa romanilor, cum cerca muiere, care avea glas mai bun, de cânta la osằ, precum acestaş şi aici în ţară să face şi pănă astădzi şi cu alăute.

Şi acestea le-am arătat ca şi dintru aceştea să să cunoască niiamul cu obicéiurile că au ieşit de la Râmŭ..." (Costin, 1958, p. 272).

Lui Miron Costin (1633-1691), de la a cărui moarte răbojul adună, iată, 330 de ani, cărturarul şi demnitarul, cu responsabilitate faţă de destinele ţării şi faţă de cuvântul scris - venerabilul inţelept (aşa îl vede imaginaţia noastră, pentru că nu s-a păstrat nici o imagine a lui, nici un portret), nu i s-au îngăduit pe acest pământ decât 58 de ani. Urmele omului Costin în istorie le desprindem din rememorările celor care i-au urmat.

Letopiseţul... lui Neculce, întâia şi cea mai avizată sursă, ni-l prezintă începând cu Predoslovia care îi atestă calitatea de predecesor (,s-au apucat dumnealui Miron Costin, vel-logofăt, de au făcut un letopisăţŭ. Şi cât n-au putut istovi Miron-logofătul 1-au istovit fiiu-său, Nicolai Costin, biv-vellogofăt, şi l-au scris di-nceputul lumii, arătând cine au trăit pre acest pământ, cu mărturii a istorici streini”), înveşnicindu-1 prin câteva crâmpeie din parcursul său pământesc, devenite legendă, şi fraze pe care le-a rostit în situaţii-limită, devenite simbol (,Şi i-au dzis vizirul să-i spuie dreptu: parele lor bine c-au luat împărăţia Cameniţa, au ba? Iar Miron au răspunsu că să teme a spune drept. Vizirul s-au jimbit a râde şi i-au dzis sî grăiască, să nu să teamă. Atunce Miron au dzisŭ că «sintem noi moldovenii bucuroşi să să lăţască în toati părţili cât de mult, iar peste țara noastră nu ne pare bine să să lăţascằ. A Aunce viziriul iară au râs şi i-au dzis: «Drept ai grăit»”; sau: „Iar Miron-logofătul au sfătuit să nu să clintească nicăiri din Domnești... «Ce putere au ei să vie asupra mării tali? Să nu dăm locul, că pământul acesta este frământat cu sângele moşilor şi a strămoşilor noştri!»”; sau: „După cum dzice un cuvât Miron-logofătul: «Mare este omul, iar la războiu prè mică-i este ţinta»" (Neculce, 1958, p. 3, $45,77,243)$.

Dintotdeauna, omul a iubit viaţa. Viaţa, darul cel mai de preț.

„Dzisu-i-au slujitorii, când l-au găsit la Bărboşi, să fugă, că nu-i departe, în Neamţu, iar el n-au priimit, ştiindu-să drept. Gândiè că l-or ducé la Iaşi şi s-a îndrepta. Iar după ce i-au vinit Macrei, şi viind zapciu după zapciu să piiară, nu 1-au mai îngăduit ş-au pus dé l-au tăiat în Roman. Şi mult s-au rugat lui Macreiu să-l ducă pân'în Iaşi, iar Macrei, ca un om rău şi de nimic, nu i-au fostu milă de sufletul stăpânu-său şi s-au grăbit de 1-au omorât. Că de 1-ar hi dus în Iaşi, poate s-ar hii îndreptat şi n-ar hii perit. Că multe sluji să tâmplă la domnii vrednicé, dé nu să grăbascu şi ferescu pe stăpâni de păcat, şi pe urmă cad la laudă şi despré stăpân, şi despré oameni, şi despré Dumnedzău. Iar acesta, ca un varvar, nefiind de neam, n-au socotit. 
Cantemir vodă dup-acéia mult să căia ce au făcut şi de multe ori plângè între toată boerimea şi blăstăma pe ciné 1-au îndemnat de au grăbit dé i-au tăiat. Că, dup-aiè, n-au trăit un an nice Cantemir vodă, ş-au murit" (Neculce, 1958, p. 111).

Recitim acest pasaj antologic, în care Neculce reconstituie, concentrat şi credibil, dramatismul, zbuciumul ultimelor clipe din viaţa celui care, tot Neculce ne spune, era dintre toţi boierii ţării mai de treabă la voroave.

Acel an crunt din istoria Moldovei, 1691, foarte îndepărtat, reverberează în epopeea lui Vladimir Beşleagă, care-şi ia ca titlu pentru ampla sa naraţiune epică, deloc întâmplător, sintagma dureros de reală şi atât de frecventă în file de cronici: Cumplite vremi, reconstituind, inspirat, tabloul vieţii şi lumii acelui secol.

Pentru Vladimir Beşleagă, cunoscutul scriitor basarabean, înţelegerea trecutului, a realităţilor vechii lumi a însemnat, implicit, propria regăsire de sine, un punct de sprijin în reconsiderarea realităţilor imediate, alimentându-i şi stimulându-i sensul şi condiţia cunoaşterii.

A citit cu sufletul Letopiseţele Ţării Moldovei. Îl putem considera un emul al marilor cronicari. Marcat de modelul uman şi comportamental al acestui înaintaş în ale scrisului, va considera necesar să limpezească trama/ sorgintea/mobilul construcţiei sale artistice.

Va şi relua, în cheie cronicărească, în chiar naraţiunea propriu-zisă: „Oh, durere şi iarăşi durere! Căci acest vaiet de cumplită jale se va lăţi peste locuri şi vremi, va răzbate prin negura anilor, ajungând până în zilele noastre, făcând să ni se oprească mintea în loc de acea mare nenorocire, să ni se taie suflarea de atâta cruzime şi nemăsurată viclenie câtă poate încăpea în unele suflete omeneşti. Dar oare atare lucruri şi tâmplări sângeroase nu s-au mai prilejit până atunci şi după aceea? Aşa este, au fost, căci cruzimea şi nedreptatea îşi află loc între oameni de când este viiaţa pe pământ. Şi atunci, de ce oare ne-ar lovi şi cutremura într-atât de adânc acea năprasnică moarte a celui dintâi mare învăţat al Moldovei?

Odată ce am purces să depăn astă încâlcită şi tristă istorisire, dator sunt cu o lămurire, care să vină a desluşi şi lumina cât de cât cetitorului pricinile ce m-au boldit la o muncă de ani de zile.

În anii de studenţie, când, pentru întâia dată, am cetit aceasta în cărţi, am fost ca lovit de trăsnet. Atunci a căzut în inima mea sămânţa acestei scrieri. Aproape douăzeci de ani a zăcut acolo până când, într-un târziu, a dat colţ şi a pornit să crească, răzbind la lumină. Așa a fost. Dar, mă vei întreba, iubite cetitorule, pentru ce am luat o brazdă atât de lată, de ce m-am apucat de o muncă atât de cuprinzătoare, dacă aş fi putut să-mi opresc luarea aminte doar asupra acelei nenorocite întâmplări? Pentru că am ţinut să văd şi să arăt cum vieţuiau oamenii de rând în acele vremi, să vădesc feluritele stări ale obştii, să încerc a vedea cu ochii minţii şi închipuirii mele viaţa întregii ţări”" (Beşleagă, 2017, p. 503). 
Atunci când „evocă epoca mai îndepărtată a Cantemireştilor şi Costineştilor, - observa Mihai Cimpoi, - fraza este limpede, aşezată, de o pastă epică densă şi colorată..., uşor neaoşizată şi muiată în parfum cronicăresc" (Cimpoi, 2011, p. 184). Reconstituirii vii şi foarte colorate a faptelor, care aminteşte de Neculce, dar şi de Creangă şi de Sadoveanu, i se adaugă destăinuiri emoţionante (text în text), vibrante prin omenescul lor, cum e şi fragmentul deja amintit.

Volumul I al trilogiei apărea în 1985, cu titlul Sânge pe zăpadă, la editura Literatura artistică, urmat de alte două ediţii, în 1990 (Hyperion) şi 2003 (Litera).

O ediţie completă apare la Cartier, în 2017 - invitaţie la noi lecturi. Dar despre asta într-o abordare viitoare.

Opera cronicarilor, afirmând valorile vieţii, promovează imaginea umanităţii noastre medievale. Anii din urmă scot la lumină mai multe volume monografice, ceea ce denotă că scrisul nostru vechi rămâne în aria de interes a cercetării literare. Cărţi importante, substanţiale, frumoase se tipăresc la Bucureşti, la Iaşi, se retipăresc la Chişinău, dar şi volume apărute în Basarabia sunt reluate de edituri din ţară - un flux înnoitor de redefiniri a epocilor de altădată. Demersul ştiinţific vine cu alt instrumentar şi altă viziune, jalonând alte/noi etape interpretative.

Revenim, din timp în timp, la vechile texte, pentru că ele, incitante şi revelatoare, ne apropie de universul lumii de ieri şi ne ajută să-l prefigurăm pe cel al lumii de mâine.

Mă opresc aici. Nu şi povestea. Povestea continuă. Este însăşi viiaţa, apă omenească, pe care cuvântul şi timpul o veşnicesc.

\section{Referințe bibliografice:}

1. Antologia poeziei vechi moldoveneşti. Modele şi reconstituiri. Prefaţă, selecţie, traduceri şi note de Nicolae Dabija. Chişinău, 1987. 2017.

2. BEŞLEAGĂ, Vladimir. Cumplite vremi. Roman în trei cărţi. II (2). Chişinău,

3. CARTOJAN, Nicolae. Istoria literaturii române vechi. Prefață de Dan Horia Mazilu. Bibliografii finale de Dan Simonescu. Ediţie îngrijită de Rodica Rotaru şi Andrei Rusu. Bucureşti, 1996.

4. CÂNDEA,Virgil. Raţiunea dominantă. Cluj-Napoca, 1979.

5. CIMPOI, Mihai. Accente psihologice şi voci narative la Miron Costin. În: Cicatricea lui Ulysse. Eseuri duminicale. Chişinău, 1982.

6. CIMPOI, Mihai. Cei trei Beşleagă. În volumul omagial: Vladimir Beşleagă, omul luminat. Chişinău, 2011. Publicat iniţial în Moldova suverană, 25 iulie 1991.

7. CIOBANU, Ştefan. Istoria literaturii române vechi. Ediţie îngrijită, note şi prefaţă de Dan Horia Mazilu. Bucureşti, 1989.

8. COSTIN, Miron. Opere. Ediţie critică, cu un studiu introductiv, note, comentarii, variante, indice şi glosar de P.P. Panaitescu. Bucureşti, 1958.

9. CRISTEA, Valeriu. Introducere in opera lui Ion Neculce. Bucureşti, 1974. 
10. CURTICĂPEANU, Doina. Orizonturile vieţii în literatura veche românească (1520-1743). Bucureşti, 1975.

11. DOBRE-BOGDAN, Cristina. Imago mortis în cultura română veche (sec. XVII-XIX). Bucureşti, 2002.

12. DUȚU; Alexandru. Literatura comparată şi istoria mentalităţilor. Bucureşti, 1982.

13. EMINESCU; Mihai. Opere. VII. Publicistică. Coordonatorul ediţiei: acad. Mihai Cimpoi. Chişinău, 2001.

14. LEMNY, Ştefan. Sensibilitate şi istorie în secolul XVIII românesc. Bucureşti, 1990.

15. Literatura română medievală. Antologie alcătuită de un colectiv condus de Dan Horia Mazilu. Bucureşti, 2003. 1990.

16. MANOLESCU, Nicolae. Istoria critică a literaturii române. I. Bucureşti,

17. Marii cronicari ai Moldovei. Grigore Ureche. Miron Costin. Nicolae Costin.Ion Neculce. Ediţie, studiu introductiv, repere istoriografice, glosar de Gabriel Ştrempel. Bucureşti, 2003.

18. MAZILU, Dan Horia. Prefaţă la: Literatura română medievală. Antologie alcătuită de un colectiv condus de Dan Horia Mazilu. Bucureşti, 2003.

19. NECULCE, Ion. Letopiseţul Ţării Moldovei şi O samă de cuvinte. Text stabilit, glosar, indice şi studiu introductiv de Iorgu Iordan. Ediţia a II-a, revăzută. Bucureşti, 1959.

20. NEGRICI, Eugen. Expresivitatea involuntară. Figura spiritului creator. Imanenţa literaturii. Bucureşti, 2000.

21. VILLARI, Rosario. Introducere la: Omul baroc. Volum coordonat de Rosario Villari. Traducere de Dragoş Cojocaru. Iaşi, 2000.

22. ZUB, Alexandru. Istorie şi finalitate. În căutarea identităţii. Iaşi, 2004.

Notă: Articolul a fost realizat în cadrul proiectului de cercetare 20.80009.1606.03 Contexte socioculturale autohtone şi interconexiuni europene în creaţia populară şi literatura cultă din Basarabia (sec. XIX până în prezent), Institutul de Filologie Română „B. P.-Hasdeu” al MEC. 